Jurnal Pengurusan 55(2019) $181-192$

https://doi.org/10.17576/pengurusan-2019-55-15

\title{
Examining the Business Venture Success of Restaurants: The Role of Innovation Capability as a Mediator
}

(Mengkaji Faktor Kejayaan Pengusaha Restoran: Peranan Inovasi sebagai Pengantara)

\author{
Bee Leong Tan \\ (Thompson Tan \& Associates) \\ Cheng Ling Tan \\ (Graduate School of Business, Universiti Sains Malaysia) \\ Sook Fern Yeo \\ (Faculty of Business, Multimedia University) \\ Sock Lee Ching \\ (Graduate School of Business, Universiti Sains Malaysia)
}

ABSTRACT

This research examines successful entrepreneurial practices of small and medium restaurants in Malaysia, which includes aspects of start-up planning, financial support, networking, family support, and government support. It also investigates the mediating role of innovation capability on successful entrepreneurial practices. Purposive sampling technique was used to collect data from 390 restaurant business owners through a mailed structured questionnaire. Structural equation modeling involving SmartPLS 3.0 and SPSS 20 software were used to analyse the data and to test the hypotheses. It shows that only start-up planning, networking and innovation capacity were supported, whereas financial support, family support and government support were not supported. Results revealed that innovation capability is a significant intervening variable on the relationship between start-up planning and business venture success, as well as the relationship between networking and business venture success. The study provides practical implications to restaurant owners to actively evaluate the existing resources for better decision making.

Keywords: Restaurant; business venture success; networking; start-up planning; innovation capability.

ABSTRAK

Kajian ini meneliti amalan keusahawanan yang berjaya di restoran kecil dan sederhana di Malaysia, yang merangkumi aspek perancangan permulaan, sokongan kewangan, rangkaian, sokongan keluarga, dan sokongan kerajaan. Kajian ini juga menyiasat peranan mediasi keupayaan inovasi terhadap amalan keusahawanan yang berjaya. Teknik pensampelan purposif digunakan untuk mengumpul data dari 390 pemilik perniagaan restoran melalui soal selidik berstruktur yang dihantar. Pemodelan persamaan struktur yang melibatkan perisian SmartPLS 3.0 dan SPSS 20 digunakan untuk menganalisis data dan menguji hipotesis. Dapatan kajian menunjukkan bahawa andaian bagi permulaan perancangan, jaringan dan keupayaan inovasi adalah disokong manakala andaian bagi bantuan kewangan, sokongan keluarga dan sokongan kerajaan adalah tidak disokong. Keputusan menunjukkan keupayaan inovasi adalah pembolehubah intervensi yang signifikan terhadap hubungan antara perancangan permulaan dan kejayaan usaha perniagaan, serta hubungan antara jaringan dan kejayaan usaha perniagaan. Kajian ini memberikan implikasi praktikal kepada pemilik restoran untuk secara aktif menilai sumber-sumber sedia ada untuk membuat keputusan yang lebih baik.

Kata kunci: Restoran; kejayaan usaha perniagaan; rangkaian; permulaan perancangan; keupayaan innovasi.

\section{INTRODUCTION}

"Robust consumption fueled by a rapidly growing consumer class, rising incomes, and urbanization will generate $\$ 770$ billion in new consumer spending in ASEAN over the next few years" (Accenture Report 2015). The above statement revealed the vast market for food industry arising from urbanization and the rise of the working class, in particular, the women workforce who join the industrial world and have less time for home cooking. For restaurant operators, this indeed is welcoming news. However, the lack of knowledge and information, and cognitive willingness have resulted in high failure rate among full-service restaurant operators in ASEAN countries, in particular, the Malaysian restaurants (Bates 2006; Small Business Administration 2014). The lack of information on consumer needs and the inability of the small medium enterprises to take advantage of the rise of social networks, such as mobile connectivity, are some of the reasons for the high failure rate among full-service restaurant operators (Bernama 2006). Some of the important challenges faced by these food operators include a highly fragmented retail landscape, difficulty in customer acquisition and maintaining customer loyalty, complex, and competitive environment (Accenture Report 2015). In the fundamental sense, the restaurant business becomes very competitive, 
and this has hindered the entrepreneurs' venture success Hence, it is crucial to understand the determinants that would help the entrepreneur to succeed in the business. Among the variables, start-up planning, financial support, networking, family support and government support are found to be tied with innovation capability which can expand the entrepreneurs' venture success in business. This study would like to focus on the full-service restaurant which is classified as a small-medium enterprise (SMEs) in Malaysia. The findings derived from this research can be duplicated by other SMEs later. This paper also investigates the mediating role of innovation capability in ensuring full-service restaurant entrepreneurs' success.

\section{RESEARCH BACKGROUND}

SMEs are known to contribute to a country's economic growth and stability through the creation of new jobs and employment opportunities (Santarelli \& Vivarelli 2007). In Malaysia, 99.2 percent of the businesses registered are SMEs, which owned 56 percent of the jobs in the market (Bernama 2011). Malaysian SMEs had performed remarkably well in the last decade, with growth exceeding the average growth of the economy. Between 2011 and 2015, SMEs grew at an average annual rate of 6.7 percent, compared to the overall average growth rate of 5.3 percent in the economy. As a result, over five years, SME's contribution to GDP increased by 4.1 percent to 36.3 percent (SME Annual Report 2016). In 2016, SMEs were projected to grow at a rate of 5.0 to 5.5 percent, in line with the expected overall economic growth of 4.0 to 4.5 percent in the Malaysian economy.

Among the SME sectors, the number of micro SMEs in food services reached 117,020 in 2016 (SME Corp Malaysia - SME Statistics, 2016). Its market value increased from USD8.4 billion in 2008 to approximately USD10 billion in 2012 (Euromonitor International 2013). Among the food services, the full-service restaurants were the dominant subsector representing over one-third of the total market. The Compound Annual Growth Rate (CAGR) of full-service restaurants was 3.3 percent between 2008-2012. Although the full-service restaurants revealed a dramatical growth, only 50 percent of the new establishments survived the first five years, and only one-third survived for ten years (Small Business Administration 2014). Many firms failed drastically and were forced to close (Bates 2006). A study commissioned by Perbadanan Usahawan Nasional Berhad (Bernama 2006) discovered that about 13 percent of the entrepreneurs failed in their business venture. Malaysia may face economic and social consequences such as higher unemployment rate as well as social issues that could be detrimental to its long-term objectives of becoming an advanced nation by 2020 .

Under the $11^{\text {th }}$ Malaysia Plan, entrepreneurship has identified as one of the national priority areas towards attaining Vision 2020, and SME Corp Malaysia was established to coordinate entrepreneurship initiatives of those middle-income groups. SMEs are competitively disadvantaged due to reduced utilisation of knowledge and the subsequent entrepreneurial behaviour (Bernama 2006). Other factors have also suggested as causes of fullservice restaurants failure, but the findings are mixed and non-conclusive (Kara, Chu \& Benzing 2010). In line with this, the present study aimed at assessing the determinants of entrepreneurial attributes towards the business success of SMEs in Malaysia in general and the business success of the restaurant industry in particular. This study attempts to identify the influencing factors that can create a more resilient, efficient, and successful business entrepreneur. Besides, this study also attempts to address the literature gap of the success factors of full-service restaurants to increase the probability of business venture success. The paper organised as follows: First, a discussion on the restaurant business in Malaysia. Second, the entrepreneurs' successful venture practices are reviewed, followed by hypotheses development. Research method, data analyses, and discussion were presented towards the end of the paper.

\section{RESTAURANT BUSINESS IN MALAYSIA}

Malaysia's restaurant industry is one of the fastest growing sectors in the country's economy. The swift expansion of the restaurant industry in Malaysia is likely to see the growth in demand for the next several years. According to USDA's Foreign Agricultural Service (2017), Malaysia's restaurant industry has performed well with a growth rate of more than 54 percent for the past five years. Based on the Economic Report (2017), the food and beverages segment has expanded at 7.9 percent whereby this increase was due to consumers spending on dining at restaurants.

In the urban areas, dining out is popular among the residents because of its convenience and economic nature. Consumers either consume the food at the restaurants or pack the food and drinks for eating at home. There are two major types of restaurants, namely, the full-service restaurants and the fast-food restaurants. In the full-service restaurants, the guests are seated at the tables, while the servers serve the food and drinks. The full-service restaurants can be further categorised into fine dining and casual dining restaurants. The fast-food restaurants focus on the speed of their service and inexpensive food items. Since dining options abound, competition between restaurants is intense. Home cooking is usually a less expensive option compared to dining in restaurants. Thus, the restaurant business tends to be highly cyclical, and the meals are discretionary purchases. The restaurants' margins were determined by the management's ability to deliver a wide range of delicious menu that appeals to the consumers.

On top of these, operating costs are escalating. The raw material costs, an essential line item, at times can fluctuate wildly. Another concern is the cost of labour, particularly for service-oriented restaurants. The situation 
is aggravated with the implementation of a 6 percent Goods and Service Tax in 2015 and the reduction of subsidies, where consumers have to bear the rising operational and raw material costs. Since the industry is highly competitive with multiple source suppliers and price elasticity is high, the operators of food service business face many challenges, both internally and externally.

\section{LITERATURE REVIEW}

\section{BUSINESS VENTURE SUCCESS}

Business venture success for SMEs is very subjective. It is contingent upon the entrepreneurs' perception of reward and the result of comparison between entrepreneurs (Alstete 2008). Furthermore, business venture success is temporal and transient. This is because an entrepreneur who was once successful can suffer losses due to the changes in the economic or social environment. It is a universal phenomenon that all types of businesses engage themselves in the race for business success, in particular, the entrepreneurs of SMEs, who are the nucleus of competition. Business success is the result of actions taken by entrepreneurs who allow the firm to adapt to the external environment by managing its internal resources, thereby enhancing effectiveness and efficiency of the business unit (Keizer, Johannes \& Halman 2002). Business success is related to the overall firm achievements through efforts made to enhance growth and profitability (Gunday et al. 2011). The success of small businesses is attributed to several factors, among which are start-up planning, financial support, networking, family support, and government support.

\section{RESOURCE BASED VIEW (RBV)}

The Resource-Based View (RBV) of the firm describes a firm with resources that are scarce and valuable and capabilities (and strategic assets) that distinguish it from other firms in the marketplace and can have a competitive advantage (Hsu \& Ziedonic 2013). A firm can develop and implement strategies using these resources and capabilities to increase revenue by lowering a firm's net cost and can be valuable (Barney \& Arikan 2001: 138). These resources and capabilities can enable the firm to produce innovative products and services, which are essential to the success of the firm (Penrose 1959). Various researchers have identified several factors contributing to successfu innovation in SMEs, including customer demand, networking, management strategic orientation, process innovation and internal culture (Laforet \& Tann 2006). In particular, the entrepreneurs' network is crucial to enable success in any business venture. Besides, government support in terms of resources, professional expertise development, and cooperation between commercializing firms are vital to facilitate the commercialization of the business (Tan et al. 2017). The government support is an important strategic resource; state-affiliated firms are granted preference to access these resources. The lack of government support is an institutional barrier to a small and medium-sized enterprise. Hence, SMEs have highly required government support in resource allocation.

The RBV extension with the concept of "dynamic capabilities," enable the firm to adapt to changing business and market environments by developing and using competencies and resources (Eisenhardt \& Martin 2000; Lopez 2005). This view explains how a firm can add value for customers by creating products and services and secure a competitive advantage that is sustainable for the firm by channelling its resources into innovative capabilities (Ali et al. 2010; Hult, Hurley \& Knight 2004). The firms must be able to respond quickly with innovations to meet specific market needs. The firm may alter the market landscape by simultaneously exploring basic research areas for potentially major innovations (Chidamber \& Kon 1994). The firm business performance will be improved with the innovation efforts of the firm, which focus on nurturing and enhancing these competencies and capabilities. Innovation is described as "the whole organisation is involved in an integral activity and conditions the organisational behaviour" (Martínez-Román et al. 2011: 460). The ability of the firm to respond appropriately to environmental changes with the fast internal processes with innovative capability as a unique asset (Akman \& Yilmaz 2008; Guan \& Ma 2003). To survive environmental changes, the entrepreneur must adjust to adopt innovations over time (Hult et al. 2004) in order to increase business venture success.

The RBV holds that firm that has excellent resources, which are protected by some form of isolating mechanism to prevent their diffusion in the industry, can earn sustainable supra-normal returns. The RBV suggests that there can be heterogeneity among firms that allow some of them to sustain competitive advantage (Barney 1991, 2001). As the RBV emphasises strategic choice to maximise returns, we assimilate that a proper start-up planning is required for the entrepreneur to identify, develop and use the resources to ensure the competitiveness.

The resource-based view of an organisation will influence the field of strategic management (Newbert 2007). Meso and Smith (2000) defined a resource-based view of the organisation as a strategic asset that is rare, imperfectly imitable, valuable and cannot be substituted. From the resource-based view, some scholars explained the cornerstones of the competitive advantage (Barney 1991; Peteraf 1993; Wernerfelt 1984). Several dynamic concepts, such as integrative, absorptive, construct, higher order capacity and others to explain the ways to achieve success were put forward by scholars. Teece, Pisano and Shuen (1997) extended the resource-based view to the dynamic environment and proposed that organisations should continuously adapt and renew their resources and capabilities to adapt to the environmental changes, which are now the universal concept of dynamic capabilities. 
Competitive advantages and disadvantages over some time may change and shift. The resource-based view theory is compelling and provides a framework for understanding the evolution of capabilities over time. In the small business context, financial support has been identified as the ultimate resources for an entrepreneur to first start up the business (Ahmad \& Xavier 2012). The source of finance in small start-up firm usually come from family members. Hence, family support has been viewed as an essential form of resource for the entrepreneur to continue with the business venture.

In the strategy literature, resource-based view is the dominant framework (Newbert 2007) by attempting to explain why there are performance differences in the same industry among the different organisations (Zott 2003). As entrepreneurs make judgements about which resources are more important based on their expectations regarding the future of the venture, Lussier and Shaike (2014) also uses the resource-based theory. This study applied the resourcebased view in explaining the start-up planning, having innovation, financial support, networking, family support and government support influence on the entrepreneur's success in the business venture.

\section{START-UP PLANNING}

Start-up planning is defined as a firm founder's efforts to obtain information about the opportunity in businesses and to use that information to exploit the opportunity and create a new organisation (Delmar \& Shane 2003). Individuals who start a business venture should have the necessary skills, capabilities, knowledge, and attitudes to provide the support required for starting a business venture (Mitchell et al. 2002). Preparation of a business plan is a vital component of start-up planning (Honig 2004). The entrepreneurs' effort in preparing a detailed business plan before starting marketing efforts is found to have a positive impact on business venture success (Shane \& Delmar 2004). How well the plan adopts the business to its external environment through the management of its resources determines the firm's business performance (Keizer et al. 2002).

Previous research found that the planning behaviour of entrepreneurs and the content of the formally written business plan could help in making the business venture a success (Mazzarol, Reboud \& Soutar 2009). If the business owners have a detailed business plan that uses a pre-emptive approach before starting any marketing efforts, it will increase the innovation capability of the firm that can lead to business venture success (Bracker, Keats \& Pearson 1988). Thus, the following hypothesis is developed:

$\mathrm{H}_{1} \quad$ Start-up planning positively influences the innovation capability of the business venture.

\section{FINANCIAL SUPPORT}

Financial support is crucial for starting and developing businesses. Various studies have revealed that the major obstacle to small business success is the shortage of financial capital and sufficient cash flow. Small businesses are more particular about having access to capital than other businesses due to their difficulty in securing loans from financial institutions (Orser, Hogarth-Scott \& Riding 2000).

The start-up capitals are used for investment in product and market development during the few initial years of start-ups. However, due to the problem of lack of collaterals, such as insufficient documents to support their loan application and lack of proper financial track record, SMEs may face some difficulties in obtaining finances. This resulted in firms' inability to innovate and the inability to introduce new products and services if they are unable to secure external capital (Cooper, Gimeno-Gascon \& Woo 1994). Hence, the subsequent hypothesis is put forward:

$\mathrm{H}_{2}$ Perceived financial support positively influences the innovation capability of the business venture.

\section{NETWORKING}

Networking is described as an activity in which the entrepreneurs build and manage personal relationships within their surroundings (Carson, Cromie \& McGowan 1995). Social networking is an important determinant for SME business success (Yueh 2007). Chinese entrepreneurs, in particular, believe that knowing the right person can result in excellent business success (Liao \& Sohmen 2001). For example, entrepreneurs can gain more favourable credit terms through business contacts (Bhagavatula et al. 2008). Networking strategies include developing relationships with professional associations, family members, and friends (Manimala 1992).

Social networks are vital for business success (Blumberg \& Pfann 1999; Bruderl \& Preisendorfer 1998; Honig 1998). It is generally agreed that networking, in the form of resources embedded in the personal business networks, is critical to the success of small businesses. Business networks enable entrepreneurs to innovate through the identification of new business opportunities (Stam, Arzlanian \& Elfring 2014). Therefore, the following hypothesis is postulated:

$\mathrm{H}_{3}$ Perceived networking positively influences the innovation capability of the business venture.

\section{FAMILY SUPPORT}

Family played an important role in small business success by directly supporting the business or through networking and social community (Pisturi, Welsch \& Roberts 1997). The business may be assisted by the family domain, 
which supplies various types of resources and support For instance, family-to-business enrichment and support may serve as valuable resources to enhance business success and growth. Based on their personal preferences, entrepreneurs with family support can structure their business accordingly (Bird \& Brush 2002).

Family members also contribute to entrepreneurial business success because family members provide alternative sources of capital and a reliable source of employment (Masurel \& Smit 2000). Previous research has acknowledged the various resources a family can provide for, including social and financial capital (Danes et al. 2009; Dyer 2006). With the increase in networking and financial resources, the business can pursue more innovative products and services. Hence, the following hypothesis is formulated:

$\mathrm{H}_{4}$ Perceived family support positively influences the business venture's capacity to innovate.

\section{GOVERNMENT SUPPORT}

Considerable effort has been given by the government to help in the creation and sustainability of small businesses (Carter \& Van Auken 2006). Government helps to provide financial support and incentives to SMEs to manage the innovation capability processes, in the form of collateral-free loans and tax exemptions. Additionally, government institutions offer assistance to new start-ups by providing information, training, and infrastructure. In Malaysia, a holistic approach for SME and entrepreneurship development is provided by the government, which focuses on five key components;policy development, advisory services, guarantee and financing schemes, registration and licensing, start-up and incubation, and outreach and awareness programs. Various agencies, such as SMECorp Malaysia, Majlis Amanah Rakyat (MARA), Center for Entrepreneur Development and Research (CEDAR), Institut Keusahawanan Negara (INSKEN), and Perbadanan Usahawan Nasional Berhad (PUNB) have been set up to help the entrepreneurs ( $11^{\text {th }}$ Malaysia Plan 2015).

As evident from successful innovation among entrepreneurs in other parts of the world, the government plays a central role in creating a conducive environment for innovativeness among entrepreneurs to help in business venture success (Ferrary 2009). Hence, the following hypothesis is advanced:

$\mathrm{H}_{5} \quad$ Perceived government support positively influences the innovation capability of the business venture.

\section{INNOVATION CAPABILITY}

Innovation capability refers to the ability of the firm to seek new and better ways to implement tasks. Innovation capability may take the form of new products, new services or processes, better management and administrative systems and structures, as well as better marketing strategies (Brem \& Voigt 2009). Firms recognised the need to continually innovate by providing new products and services in today's highly competitive business environments (Brem \& Voigt 2009). By possessing capabilities and resources that are difficult to imitate by others, the firm can achieve competitive advantage (Hsu $\&$ Ziedonic 2013). The sustainability of the competitive advantage depends on the firm's ability to innovate (Yanadori \& Cui 2013). In full-service restaurants, innovation capability usually comes in the form of new menus, innovative business processes (such as home delivery, home catering, online order and delivery to offices, and booking for special functions), or stress-free and theme-based dining environment.

Innovation capability is concerned with the renewal of ongoing business processes or products and services that have stagnated within the existing business (Slater 1997). In order to adapt to environmental changes, both internally and externally, firms must be willing to adopt an innovation (Hult et al. 2004). Compared to large firms, small businesses face more challenges in the form of limited resources, lack of economies of scale, small market size, and more vulnerable to market shifts and environmental uncertainties (Cagliano, Blackmon \& Voss 2000).

For a small business to achieve long-term success, they need to have competitive advantages and possess innovative activities (Madrid-Guijarro, Garcia-Perezde-Lema \& Van Auken 2013). As innovation capability is economically profitable, small businesses should incorporate innovation capability into their business activities (Gilmore, Galbraith \& Mulvenna 2013). Given the discussion above, we posit the following hypothesis:

$\mathrm{H}_{6}$ Perceived innovation capability positively influences business venture success.

Previous studies found that having more financial support will facilitate the pursuit of innovative activities (Cooper et al. 1994). Financial resources can be used for experimentation with new products and services which in turn will lead to business success. Besides that, business owners with a considerable amount of well-developed social network know where to look for opportunities (Shane 2000), which leads to innovation capability and eventually small business success. These networking resources are important primarily because they encourage innovation capability that result in small business success.

The "family embeddedness" perspective of new venture creation, whereby business owner family domain impacts on the work domain and lead to business venture success (Aldrich \& Cliff 2003). The support given by family members allows the entrepreneur to launch decisions on innovative products and services for better business performance. On the other hand, the government can create the right economic, fiscal, 
and regulatory framework, as well as infrastructure for innovation capability and entrepreneurship to flourish. The government can also help to raise the awareness towards the benefits of innovation capability and at the same time provide sufficient financial resources for efficient business support services (Ferrary 2009). Thus, the following hypothesis is postulated:

$\mathrm{H}_{7}$ Innovation capability mediates the relationship between start-up planning and business venture success.

$\mathrm{H}_{8}$ Innovation capability mediates the relationship between financial support and business venture success.

$\mathrm{H}_{9}$ Innovation capability mediates the relationship between networking and business venture success.

$\mathrm{H}_{10}$ Innovation capability mediates the relationship between family support and business venture success.

$\mathrm{H}_{11}$ Innovation capability mediates the relationship between government support and business venture success.

\section{METHODOLOGY}

\section{SAMPLE AND DATA COLLECTION PROCEDURE}

The respondents of this study were restaurant owners in Malaysia. The number of samples was calculated using the G-Power software. We set the effect size as small (0.15) and the power needed as 0.80 , the minimum sample size required was 92 . The questionnaires were mailed to the restaurant owners, who were given one month to send back in a prepaid self-addressed envelope. One follow-up was served after two weeks of questionnaire distribution, whereby the respondents were reminded of the need to return the completed form in two-weeks' time. A total of 139 questionnaires were collected within the stipulated period. During the screening, only 137 were usable and subsequently analysed.

\section{MEASURES AND ANALYSIS}

The questionnaire comprises of the following constructs: (1) business venture success was gauged using five items adapted from Chu et al. (2011); (2) innovation capability was measured using seven items adapted from Al-Ansari, Pervan and $\mathrm{Xu}$ (2013); (3) start-up planning was assessed via three items adapted from Tipu and Arain (2011); (4) financial support was measured using five items adapted from Teoh and Chong (2008); (5) networking was measured using four items adapted from Brinckmann (2007); (6) family support was measured via three items adapted from Powell and Eddleston (2013); and (7) government support was gauged using six items adapted from Indarti and Langenberg (2004)(Appendix A). The respondents used a five-point Likert scale (" 1 " = "strongly disagree" to "5" = "strongly agree") to indicate their level of agreement or disagreement with the statements provided.

\section{RESULTS}

SAMPLE PROFILE

The profile of respondents is depicted in Table 1.

TABLE 1. Profile of respondents

\begin{tabular}{lcc}
\hline Variable & Frequency & Percent \\
\hline Age Group & & \\
$16-25$ & 5 & 3.6 \\
$26-35$ & 70 & 51.1 \\
$36-45$ & 37 & 51.1 \\
$46-55$ & 17 & 12.4 \\
56 and above & 8 & 5.8 \\
Race & & \\
Malay & 19 & 13.9 \\
Chinese & 109 & 79.6 \\
Indian & 4 & 2.9 \\
Others & 5 & 3.6 \\
Marital Status & & \\
Single & 47 & 34.3 \\
Married & 90 & 65.7 \\
Qualification & & \\
Secondary & 39 & 28.5 \\
Diploma & 18 & 54.0 \\
Bachelor & 74 & \\
Master & 5 & \\
\hline
\end{tabular}

\section{MEASUREMENT MODEL RESULTS}

Factor loadings, composite reliability (CR), and average variance extracted (AVE) were used to assess the convergence validity of the constructs (Hair et al. 2013). As the loadings of all construct indicators shall exceed the value of 0.5 (Hair et al. 2011), FS3 (0.363), FS4 (0.115), FS5 (-0.183), FMS1 (0.333), GS1 (-0.197), GS2 (-0.376), GS4 (-0.238), GS6 (-0.089) and IN2 (0.390) were deleted due to its loading was below the recommended value. The AVE of all constructs was satisfactory (ranged from 0.669 to 0.941 ) after the deletion of the above items. Composite reliability is within the threshold suggested by Nunally and Bernstein (1994), as shown in Table 2. Thus, it can be concluded that the measurement model is reliable and demonstrates adequate convergent validity.

Next, the measurement model is tested on its discriminant validity. Two criteria were used to check for discriminant validity: the heterotrait-monotrait ratio of correlations (HTMT) (Henseler, Ringle \& Sarstedt 2014) and cross-loadings (Hair et al. 2012). As depicted in Table 3 , all the variables have adequate discriminant validity because the HTMT values are less than 0.90 . 
TABLE 2. Assessment of measurement model

\begin{tabular}{|c|c|c|c|c|c|c|c|}
\hline Construct & $\begin{array}{l}\text { Retained } \\
\text { Items }\end{array}$ & $\begin{array}{l}\text { Deleted } \\
\text { Items }\end{array}$ & $\begin{array}{c}\text { No. of Items } \\
\text { before deletion }\end{array}$ & $\begin{array}{c}\text { No.of Item } \\
\text { deleted }\end{array}$ & Loadings & $\begin{array}{c}\text { Composite } \\
\text { Reliability (CR) }\end{array}$ & $\begin{array}{l}\text { Average Variance } \\
\text { Extracted (AVE) }\end{array}$ \\
\hline Start-Up Planning & SP1 & & 3 & - & 0.843 & 0.877 & 0.706 \\
\hline \multirow[t]{2}{*}{ Planning } & SP2 & & & & 0.741 & & \\
\hline & SP3 & & & & 0.927 & & \\
\hline \multirow[t]{5}{*}{ Financial Support } & FS1 & & 5 & 3 & 0.957 & 0.966 & 0.934 \\
\hline & FS2 & & & & 0.976 & & \\
\hline & & FS3 & & & 0.363 & & \\
\hline & & FS4 & & & 0.115 & & \\
\hline & & FS5 & & & -0.183 & & \\
\hline \multirow[t]{4}{*}{ Networking } & NW1 & & 4 & - & 0.695 & 0.887 & 0.669 \\
\hline & NW2 & & & & 0.640 & & \\
\hline & NW3 & & & & 0.947 & & \\
\hline & NW4 & & & & 0.942 & & \\
\hline \multirow[t]{3}{*}{ Family Support } & & FMS1 & 3 & 1 & 0.333 & 0.970 & 0.941 \\
\hline & FMS2 & & & & 0.973 & & \\
\hline & FMS3 & & & & 0.967 & & \\
\hline \multirow[t]{6}{*}{ Government Support } & & GS1 & 6 & 4 & -0.197 & 0.899 & 0.817 \\
\hline & & GS2 & & & -0.376 & & \\
\hline & GS3 & & & & 0.931 & & \\
\hline & & GS4 & & & -0.238 & & \\
\hline & GS5 & & & & 0.877 & & \\
\hline & & GS6 & & & -0.089 & & \\
\hline \multirow[t]{7}{*}{ Innovation Capability } & IN1 & & 7 & 1 & 0.866 & 0.953 & 0.772 \\
\hline & IN2 & & & & 0.390 & & \\
\hline & IN3 & & & & 0.832 & & \\
\hline & IN4 & & & & 0.943 & & \\
\hline & IN5 & & & & 0.939 & & \\
\hline & IN6 & & & & 0.929 & & \\
\hline & IN7 & & & & 0.744 & & \\
\hline \multirow[t]{5}{*}{ Business Success } & BS1 & & 5 & - & 0.957 & 0.978 & 0.901 \\
\hline & BS2 & & & & 0.957 & & \\
\hline & BS3 & & & & 0.951 & & \\
\hline & BS4 & & & & 0.947 & & \\
\hline & BS5 & & & & 0.933 & & \\
\hline
\end{tabular}

TABLE 3. Heterotrait-Monotrait Ratio (HTMT)

\begin{tabular}{llllllll}
\hline & BS & FMS & FS & GS & IN & NW & SP \\
\hline BS & & & & & & & \\
FMS & 0.421 & & & & & & \\
FS & 0.375 & 0.443 & & & & \\
GS & 0.134 & 0.348 & 0.166 & & & \\
IN & 0.668 & 0.403 & 0.430 & 0.207 & & \\
NW & 0.571 & 0.531 & 0.539 & 0.244 & 0.875 & & \\
SP & 0.588 & 0.335 & 0.605 & 0.216 & 0.762 & 0.868 & \\
\hline
\end{tabular}

BS = Business Success, FMS = Family Support, FS = Financial Support, GS = Government Support, IN = Innovation Capability, NW = Networking, $\mathrm{SP}=$ Start-up Plan

For cross-loadings, each indicator should load the largest on the construct it is intended to measure. Table 4 presents the cross loading for each item. In sum, the measurement model demonstrated adequate discriminant validity.
Figure 1 shows the SmartPLS measurement model results. The $\mathrm{R}^{2}$ value of business success was 0.409 , suggesting that 40.9 percent of the variance in business success can be explained by the five independent variables. 
TABLE 4. PLS Result of main loadings and cross loadings

\begin{tabular}{lccccccc}
\hline Variable & $\begin{array}{c}\text { Business } \\
\text { Success }\end{array}$ & $\begin{array}{c}\text { Family } \\
\text { Support }\end{array}$ & $\begin{array}{c}\text { Financial } \\
\text { Support }\end{array}$ & $\begin{array}{c}\text { Govt } \\
\text { Support }\end{array}$ & $\begin{array}{c}\text { Innovation } \\
\text { Capability }\end{array}$ & Network & Start-Up Plan \\
\hline BS1 & $\mathbf{0 . 9 5 7}$ & 0.423 & 0.369 & 0.063 & 0.643 & 0.541 & 0.555 \\
BS2 & $\mathbf{0 . 9 5 7}$ & 0.432 & 0.349 & 0.110 & 0.630 & 0.529 & 0.544 \\
BS3 & $\mathbf{0 . 9 5 1}$ & 0.342 & 0.332 & 0.118 & 0.606 & 0.492 & 0.537 \\
BS4 & $\mathbf{0 . 9 4 7}$ & 0.361 & 0.330 & 0.112 & 0.601 & 0.469 & 0.483 \\
BS5 & $\mathbf{0 . 9 3 3}$ & 0.358 & 0.303 & 0.151 & 0.549 & 0.425 & 0.440 \\
FMS2 & 0.422 & $\mathbf{0 . 9 7 3}$ & 0.394 & 0.257 & 0.388 & 0.501 & 0.336 \\
FMS3 & 0.361 & $\mathbf{0 . 9 6 7}$ & 0.400 & 0.335 & 0.350 & 0.434 & 0.243 \\
FS1 & 0.355 & 0.429 & $\mathbf{0 . 9 5 7}$ & 0.139 & 0.331 & 0.425 & 0.514 \\
FS2 & 0.336 & 0.371 & $\mathbf{0 . 9 7 6}$ & 0.129 & 0.439 & 0.470 & 0.548 \\
GS3 & 0.105 & 0.319 & 0.110 & $\mathbf{0 . 9 3 1}$ & 0.182 & 0.164 & 0.138 \\
GS5 & 0.104 & 0.216 & 0.144 & $\mathbf{0 . 8 7 7}$ & 0.138 & 0.193 & 0.191 \\
IN1 & 0.460 & 0.290 & 0.365 & 0.089 & $\mathbf{0 . 8 6 6}$ & 0.667 & 0.580 \\
IN3 & 0.578 & 0.289 & 0.308 & 0.101 & $\mathbf{0 . 8 3 2}$ & 0.627 & 0.517 \\
IN4 & 0.609 & 0.364 & 0.337 & 0.154 & $\mathbf{0 . 9 4 3}$ & 0.751 & 0.683 \\
IN5 & 0.579 & 0.414 & 0.360 & 0.144 & $\mathbf{0 . 9 3 9}$ & 0.754 & 0.661 \\
IN6 & 0.609 & 0.351 & 0.360 & 0.232 & $\mathbf{0 . 9 2 9}$ & 0.723 & 0.648 \\
IN7 & 0.527 & 0.286 & 0.424 & 0.224 & $\mathbf{0 . 7 4 4}$ & 0.568 & 0.541 \\
NW1 & 0.324 & 0.239 & 0.498 & 0.229 & 0.525 & $\mathbf{0 . 6 9 5}$ & 0.427 \\
NW2 & 0.328 & 0.279 & 0.258 & 0.002 & 0.464 & $\mathbf{0 . 6 4 0}$ & 0.615 \\
NW3 & 0.499 & 0.475 & 0.386 & 0.195 & 0.757 & $\mathbf{0 . 9 4 7}$ & 0.664 \\
NW4 & 0.510 & 0.526 & 0.397 & 0.182 & 0.749 & $\mathbf{0 . 9 4 2}$ & 0.621 \\
SP1 & 0.492 & 0.201 & 0.575 & 0.222 & 0.649 & 0.572 & $\mathbf{0 . 8 4 3}$ \\
SP2 & 0.299 & 0.190 & 0.274 & -0.025 & 0.361 & 0.445 & $\mathbf{0 . 7 4 1}$ \\
SP3 & 0.523 & 0.348 & 0.476 & 0.178 & 0.660 & 0.726 & $\mathbf{0 . 9 2 7}$ \\
\hline
\end{tabular}

Note: Bold values are items which have loadings above 0.50

$\mathrm{BS}=$ Business Success, FMS = Family Support, FS = Financial Support, GS = Government Support, IN = Innovation Capability, NW = Networking, $\mathrm{SP}=$ Start-up Plan.

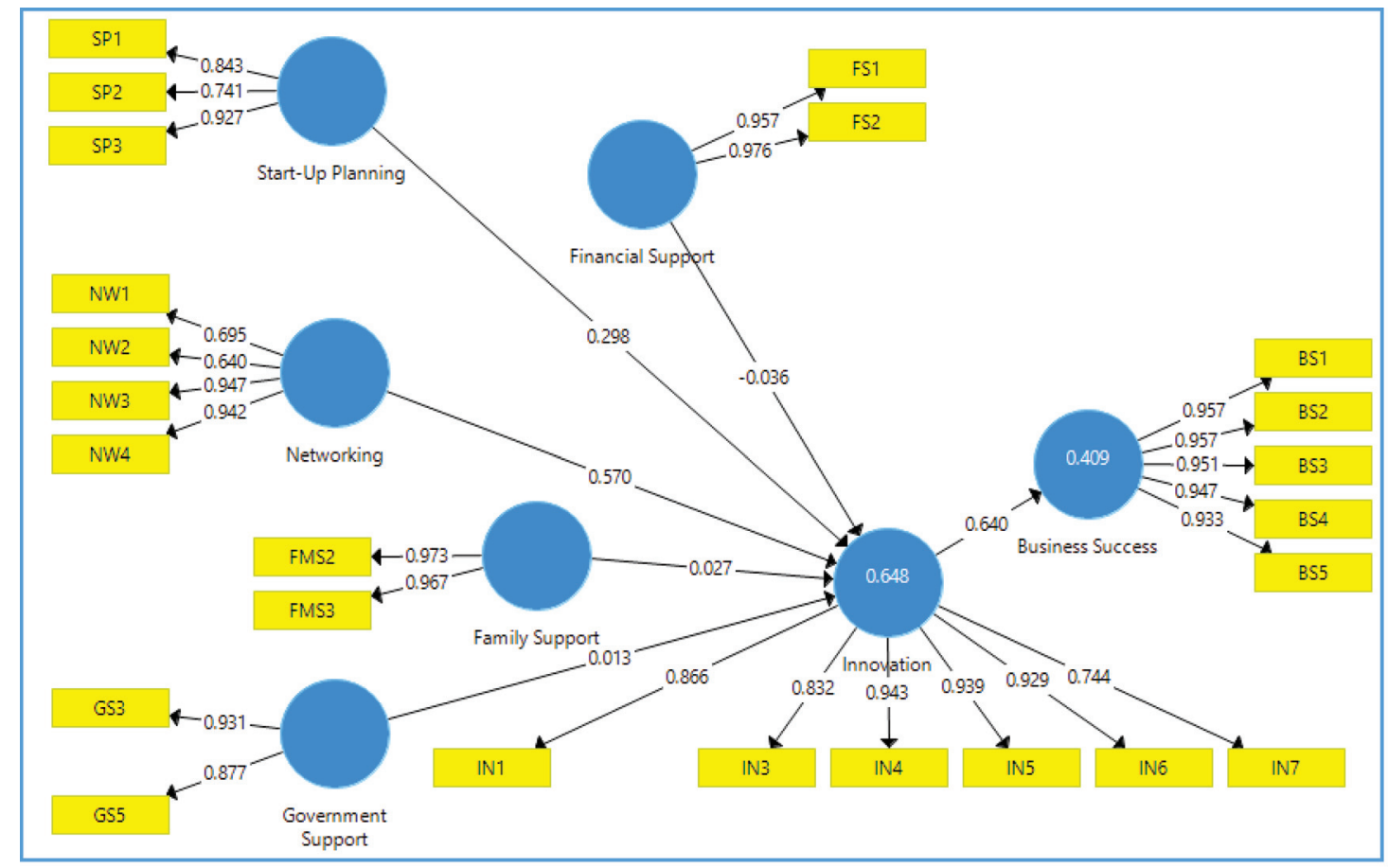

FIGURE 1. Measurement model 


\section{STRUCTURAL MODEL RESULTS}

We proceed to test the hypotheses through path analysis by running the bootstrapping procedure with 5000 resamples in order to test the significance of the regression coefficients. The coefficient values and $t$ values suggested that $\mathrm{H}_{1}, \mathrm{H}_{3}$, and $\mathrm{H}_{6}$ were statistically significant. This means start-up planning is positively and significantly related to innovation capability $\left(\mathrm{H}_{1}: \beta=0.297, \mathrm{p}<\right.$ 0.01 , networking is positively and significantly related to innovation capability $\left(\mathrm{H}_{3}: \beta=0.57, \mathrm{p}<0.01\right)$, and innovation capability is positively and significantly related to business success $\left(\mathrm{H}_{6}: \beta=0.64, \mathrm{p}<0.01\right)$. Therefore, hypotheses $\mathrm{H}_{1}, \mathrm{H}_{3}$ and $\mathrm{H}_{6}$ were supported, while $\mathrm{H}_{2}, \mathrm{H}_{4}$, and $\mathrm{H}_{5}$ were not supported (Table 5).
In addition, the hypothesis with the mediating effect of innovation capability was tested, and the results are shown in Table 6. The critical values for the two-tailed test were employed where 1.96 (the significant level at 5 percent), and 2.57 (the significant level at 1 percent) are the thresholds for the significance of the relationship. The bootstrapping results indicate that the coefficient value and $t$ value for $\mathrm{H}_{7}$ and $\mathrm{H}_{9}$ were statistically significant. This means innovation capability has mediating effect on start-up planning $\left(\mathrm{H}_{7}: \beta=0.190, \mathrm{p}<0.01\right)$ and networking $\left(\mathrm{H}_{9}: \beta=0.365, \mathrm{p}<0.01\right)$. Therefore, Hypotheses $\mathrm{H}_{7}$ and $\mathrm{H}_{9}$ were supported, while $\mathrm{H}_{8}, \mathrm{H}_{10}$, and $\mathrm{H}_{11}$ were not supported (Table 6).

TABLE 5. Hypotheses testing (direct effect)

\begin{tabular}{|c|c|c|c|c|c|c|}
\hline Hypotheses & Relationship & $\begin{array}{c}\text { Beta } \\
\text { Value } \\
(\beta)\end{array}$ & $\begin{array}{c}\text { Sample } \\
\text { Mean } \\
\text { (M) }\end{array}$ & $\begin{array}{l}\text { Standard } \\
\text { Deviation } \\
\text { (STDEV) }\end{array}$ & $\begin{array}{l}\text { T Statistics } \\
(\mathrm{O} / \mathrm{STDEV})\end{array}$ & Decision \\
\hline $\mathrm{H}_{1}$ & Start-up Planning -> Innovation Capacity & 0.297 & 0.310 & 0.084 & $3.548 * *$ & Supported \\
\hline $\mathrm{H}_{2}$ & Financial Support -> Innovation Capacity & -0.036 & -0.035 & 0.061 & 0.599 & Not Supported \\
\hline $\mathrm{H}_{3}$ & Networking -> Innovation Capacity & 0.570 & 0.558 & 0.084 & $6.795 * *$ & Supported \\
\hline $\mathrm{H}_{4}$ & Family Support -> Innovation Capacity & 0.027 & 0.022 & 0.068 & 0.399 & Not Supported \\
\hline $\mathrm{H}_{5}$ & Government Support -> Innovation Capacity & 0.013 & 0.017 & 0.058 & 0.223 & Not Supported \\
\hline $\mathrm{H}_{6}$ & Innovation Capacity -> Business Success & 0.640 & 0.641 & 0.052 & $12.271 * *$ & Supported \\
\hline
\end{tabular}

Note: ** denotes $\mathrm{P}<0.01, *$ denotes $\mathrm{P}<0.05$ (One-tailed test)

TABLE 6. Hypotheses testing (indirect effect)

\begin{tabular}{clccccc}
\hline Hypotheses & \multicolumn{1}{c}{ Relationship } & $\begin{array}{c}\text { Beta } \\
\text { Value } \\
(\beta)\end{array}$ & $\begin{array}{c}\text { Sample } \\
\text { Mean } \\
(\mathrm{M})\end{array}$ & $\begin{array}{c}\text { Standard } \\
\text { Deviation } \\
\text { (STDEV) }\end{array}$ & $\begin{array}{c}\text { T Statistics } \\
(\mathrm{O} / \text { STDEV) }\end{array}$ & Decision \\
\hline $\mathrm{H}_{7} \quad$ & $\begin{array}{l}\text { Start-up Planning -> Innovation Capacity -> } \\
\text { Business Success }\end{array}$ & 0.190 & 0.199 & 0.058 & $3.304^{* *}$ & Supported \\
$\mathrm{H}_{8}$ & $\begin{array}{l}\text { Financial Support -> Innovation Capacity -> } \\
\text { Business Success }\end{array}$ & -0.023 & -0.023 & 0.039 & 0.602 & Not Supported \\
$\mathrm{H}_{9} \quad \begin{array}{l}\text { Networking -> Innovation Capacity -> } \\
\text { Business Success }\end{array}$ & 0.365 & 0.357 & 0.062 & $5.914^{* *}$ & Supported \\
$\mathrm{H}_{10}$ & $\begin{array}{l}\text { Family Support -> Innovation Capacity -> } \\
\text { Business Success }\end{array}$ & 0.017 & 0.015 & 0.044 & 0.395 & Not Supported \\
$\mathrm{H}_{11}$ & $\begin{array}{l}\text { Government Support -> Innovation Capacity -> } \\
\text { Business Success }\end{array}$ & 0.008 & 0.011 & 0.037 & 0.223 & Not Supported \\
\hline
\end{tabular}

Note: ** denotes $\mathrm{P}<0.01, *$ denotes $\mathrm{P}<0.05$ (Two-tailed test)

\section{MANAGERIAL IMPLICATION}

This study aimed to examine the factors that influence the business venture success of restaurants in Malaysia. Results indicated that five of the hypotheses were supported while the other six hypotheses were rejected. The five supported hypotheses are: start-up planning and networking had a significant positive relationship with innovation capability, and innovation capability had a significant positive effect on business success. Besides, innovation capability has shown to mediate the relationship between start-up planning and business venture success, and the relationship between networking and business venture success. Conversely, the six unsupported hypotheses were that financial support, family support, and government support had no significant effect on the capability of a business venture to innovate. Also, innovation capability was found to have no mediating effect on the relationship between financial support, family support, and government support and business venture success.

Since start-up planning has a significant and positive influence on the firm's ability to innovate, the new start- 
up businesses should ensure that they have a specific business plan involving new products (for example new menu) or services. Therefore, planning is essential for restaurant businesses if they want the business venture to be successful. This finding is aligned with the previous research by Lussier and Shaike (2014) whereby they also found that start-up planning has a significant positive influence on business which will increase their chance of success.

Networking has also shown to have a significant and positive influence on the level of innovation capability of restaurants. Networks significantly affect the way the restaurants are developed, managed, sustained, and maintained (Jack 2010; Omri \& Frikha 2012; Omri \& Ayadi-Frikha 2014). This finding supports the findings of previous studies that the positive effects of social networks increase the restaurant's ability to innovate (Adler \& Kwon 2002; Rogers 2004). This study also revealed that innovation capability had a significant and positive influence on business venture success. However, the findings showed that there is no positive significant influence of financial support on innovation capability. Financial support may have both direct and indirect influences on entrepreneurial success (Cooper et al. 1994). Besides, it was also found that the experimentation with new practices and strategies which will allow businesses to pursue new development opportunities with the use of financial resources. Its direct effects include the ability to meet funding requirements and to undertake more aggressive strategies. For the indirect effects, the financial capital available may provide better opportunities for staff training and innovation capability. The results of the findings that family support has no significant influence on innovation capability is also an exception. Previous studies have acknowledged that family support can provide various resources to an organisation (Olson et al. 2003). Many entrepreneurs received interpersonal assistance from the family members (Danes et al. 2008; Rogoff \& Heck 2003). However, the findings of this study are contrary to the findings of previous studies. This may be because the restaurant owners do not see the need to obtain family support to innovate. One of the possible explanation is that the restaurant owners are already doing quite well in their business and already have sufficient employees to support their businesses, and they also can create innovative ideas, products and services on their own.

Another finding of this study is that government support does not significantly influence the level of innovation capability in restaurants. One of the possible reason for the insignificant relationship is that the restaurant owners may not be aware of the various programs available. Hence, they do not seek or look for government support in their restaurant business. Innovation capability is found to have significant positive influence on SME business success. This finding is consistent and supported by various studies (Gopalakrishnan 2000; Zehir et al. 2011). Many organisations are aware that innovation capability is the main tenet of growth and business success
(Cefis \& Marsili 2006; Madrid-Guijarro et al. 2013; Roberts \& Amit 2003; Thornhill 2006; Yannis et al. 2000). In whatever form innovation capability is found, in the uncertain economic and political climate of the modern world, it remains an essential component in creating a successful business. Hence, innovation capability is the most critical indicator of an organisation's performance (Calantone, Cavusgil, Zhao 2002).

Besides, the findings of this study showed that innovation capability mediates the relationship between start-up planning and business success. It is clear that the degree of innovation capability is related in terms of new products and services. One of the core competencies of small entrepreneurial businesses is that they are good at innovating business processes, which is integral to a capability to innovate new product or services. If a small business decides to innovate new products or services, it has to make some plan. However, some business owners may have no time for planning because market forces dictate what they do, as suggested by Riseeuw and Masurel (1994), who found the absence of a link between planning and business performance. They argued that quite often in a dynamic environment planning can be counterproductive. Other empirical studies provide some mixed results. For example, Shrader Taylor and Dalton (1989) find that operational planning has a positive impact on performance, but the association between strategic planning and performance is not significant. In another study conducted by Robinson and Pearce (1983), planning was found to have no significant relationship with business performance.

The findings of this study do not support that innovation capability mediates the relationship between financial support and business success. However, most of the previous findings revealed that the pursuit of resourceintensive development strategies would be enhanced by having greater financial capital (Cooper et al. 1994). It was found that financial resources allow experimentation with new practices and strategies that will create new development opportunities for businesses. The availability of financial resources will also lead to an increase in innovation capability, which will result in business success. However, the findings of this study are different from the results achieved in the previous studies. One of the possible reason is that the restaurant owners may not be facing any financial difficulties and have sufficient internally generated funds to finance their businesses and therefore do not see the need for financial support.

The finding that innovation capability mediates the relationship between networking and business success is congruent with the findings of previous studies (Kim, Aldrich \& Keister 2006). With a considerable amount of well-developed social networks, business owners have access to new opportunities (Shane 2000), which they can exploit (Kim et al. 2006) for greater business success. These networking resources help the entrepreneurs to innovate to attain a higher level of development. 


\section{CONCLUSION}

Innovation capability is an important agenda in the Malaysian Transformation Program. The Malaysian government has envisaged transforming Malaysia to innovation-centred economy from a knowledgebased economy by leveraging on the innovativeness, productivity, and participation of all. The insights obtained from this research will assist SMEs to achieve sustainability and competitiveness in the dynamic business environment. Even though the findings are interesting, it has several limitations in this study and needs to be cautiously viewed. First of all, the demographics are not representative of the general populations where the majority of respondents are Chinese (79.6\%), and education background are bachelor degree above $(54.0 \%)$. Therefore, the result of the findings may not be able to offer a generalised view of the findings. Secondly, the targeted restaurants business owners are only limited to Penang. The outcomes obtained may not be able to be generalised for use across different regions. Thus, future research may incorporate the whole of Malaysia for a large sample size to improve the conclusion of the findings. Last but not least, this research was based on an analysis of data that has been collected at a single point in time. In other words, it could mean the results might be different if the research is conducted at different times such as during prosperous years or recession. For example, during the recession, the timing of starting a business venture may be more critical.

\section{REFERENCES}

Accenture. 2015. ASEAN's billion dollar opportunity. Available at https://foodindustry. asia/asean-s-billion-dollaropportunity

Adler, P.S. \& Kwon, S.W. 2002. Social capital: Prospects for a new concept. Academy of Management Review 27(1): $17-40$.

Ahmad, S.Z. \& Xavier, S.R. 2012. Entrepreneurial environments and growth: Evidence from Malaysia GEM data. Journal of Chinese Entrepreneurship 4(1): 50-69.

Akman, G. \& Yilmaz, C. 2008. Innovation capacity, Innovation strategy and market orientation. International Journal of Innovation Management 12(1): 69-111.

Al-Ansari, Y., Pervan, S. \& Xu, J. 2013. Innovation and business performance of SMEs: The case of Dubai. Education, Business and Society: Contemporary Middle Eastern Issues 6(3/4): 162-180.

Aldrich, E.H. \& Cliff, J.E. 2003. The pervasive effects of family on entrepreneurship: Toward a family embeddedness perspective. Journal of Business Venturing 18(5): 573596.

Ali, A., Brush, C., De Castro, J., Lange, J., Lyons, T., Meyskens, M., Onochie, J., Phinisee, I., Rogoff, E., AlSuhu \& Whitman, J. 2010. Global Entrepreneurship Monitor National Entrepreneurial Assessment for the United States of America.

Alstete, J. 2008. Aspects of entrepreneurial success. Journal of Small Business and Enterprise Development 15(3): 584-594.
Barney, J.B. 1991. Firm resources and sustained competitive advantage. Journal of Management 17(1): 99-120.

Barney, J.B. 2001. Is the resource-based 'view' a useful perspective for strategic management research? Yes. Academic of Management Review 2(1): 41-56.

Bates, T. 2006. Analysis of young, small firms that have closed: Delineating successful from unsuccessful closures. Journal of Business Venturing 20(3): 343-359.

Bernama. 2006. Available at http://www.bernama.com/bernama/ v3/news_business.php?id $=209489$.

Bhagavatula, S., Elfring, T., van Tilburg, A. \& vandeBunt, G.G. 2010. How social and human capital influence opportunity recognition and resource mobilization in India's handloom industry. Journal of Business Venturing 25: 245-260.

Bird, B. \& Brush, C. 2002. A gendered perspective on organizational creation. Entrepreneurship Theory and Practice 26(3): 41-65.

Blumberg, B.F. \& Pfann, G.A. 1999. Social capital and the selfemployment decision. Unpublished manuscript Maastricht University, Business Investment Research Center.

Bracker, J.S., Keats, B.W. \& Pearson, J.N. 1988. Planning and financial performance among small firms in a growth industry. Strategic Management Journal 9: 591-603.

Brem, A. \& Voigt, K. 2009. Integration of market pull and technology push in the corporate front end and innovation management - Insights from the German software industry. Technovation 29(5): 351-367.

Brinckmann, J. 2007. Competence of Top Management Teams and Success of New Technology-Based Firms A Theoretical and Empirical Analysis Concerning Competencies of Entrepreneurial Teams and the Development of Their Ventures. Springer: Deutscher Universitätsverlag.

Bruderl, J. \& Preisendorfer, P. 1998. Network support and the success of newly founded businesses. Small Business Economics 19: 213-225.

Cagliano, R., Blackmon, K. \& Voss, C. 2000. Small firms under the microscope: international differences in production/ operation management practices and performance. Integrated Manufacturing Systems 12(7): 469-482.

Calantone, R., Cavusgil, S. \& Zhao, Y. 2002. Learning orientation, firm innovation capability, and firm performance. Industrial Marketing Management 31: 515-524.

Carson, D., Cromie, S., McGowan, P. \& Hill, J. 1995. Marketing and Entrepreneurship in SMEs. Englewood Cliffs, NJ: Prentice Hall.

Carter, R. \& van Auken, H. 2006. Small firm bankruptcy. Journal of Small Business Management 44(4): 493-512.

Cefis, E. \& Marsili, O. 2006. Survivor: the role of innovation in firm's survival. Research Policy 35(5): 626-641.

Chidamber, S.R. \& Kon, H.B. 1994. A research retrospective of innovation inception and success: The technology-push, demand-pull question. International Journal of Technology Management 9: 94-112.

Chu, H.M., Kara, O., Zhu, X. \& Gok, K. 2011. Chinese entrepreneurs: Motivation, success factors, problems, and business-related stress. Journal of Chinese Entrrepreneurship 13(2): 84-111.

Cooper, A.C., Gimeno-Gascon, F.J. \& Woo, C.Y. 1994. Initial human and financial capital as predictors of new venture performance. Journal of Business Venturing 9: 371-395.

Danes, S.M., Lee, J., Stafford, K. \& Heck, R.K.Z. 2008. The effects of ethnicity, families and culture on entrepreneurial experience: An extension of sustainable family business 
theory. Journal of Development Entrepreneurship 13 269-288.

Danes, S.M., Stafford, K., Haynes, G. \& Amarapurkar, S.S. 2009. Family capital of family firms, bridging human, social, and financial capital. Family Business Review 22: 199-216.

Delmar, F. \& Shane, S. 2003. Does business planning facilitate the development of new ventures?. Strategic Management Journal 2: 1165-1185.

Dyer, W.G., Jr. 2006. Examining the "family effect" on firm performance. Family Business Review 19: 253-273.

Economic Planning Unit, Prime Minister's Department. 2016. Eleventh Malaysia Plan, Strategy Paper 18: Translating Innovation to Wealth. Available at http://rmk11.epu.gov. my/ pdf/strategy-paper/Strategypercent20Paperpercent2018. pdf.

Eisenhardt, K.M. \& Jeffrey, A.M. 2000. Dynamic capabilities: What are they? Strategic Management Journal 21: 11051121

Ferrary, M. 2009. The role of venture capital firms in Silicon Valley's complex innovation network. Economy and Society 38(2): 326-359.

Gilmore, A., Galbraith, B. \& Mulvenna, M. 2013. Perceived barriers to participation in R\&D programmes for SMEs within the European Union. Technology Analysis \& Strategic Management 25(3): 329-339.

Gopalakrishnan, S. 2000. Unraveling the links between dimensions of innovation and organizational performance. The Journal of High Technology Management Research 11(1): 137-153

Guan, J. \& Ma, N. 2003. Innovative capability and export performance of Chinese firms. Technovation 23(9): 737747.

Gunday, G., Ulusoy, G., Kilic, K. \& Alpkan, L. 2011. Effects of innovation types on firm performance International Journal of Production Economies 133: 662-676.

Hair, J.F., Ringle, C.M. \& Sarstedt, M. 2011. PLS-SEM: Indeed a silver bullet. Journal of Marketing Theory and Practice 19(2): 139-151.

Hair, J.F., Hult, G.T.M., Ringle, C.M. \& Sarstedt, M. 2013. A Premer on Partial Least Squares Structural Equation Modeling (PLS-SEM). Thousand Oaks: Sage.

Hair, J. F., Sarstedt, M. \& Ringle, C. M. 2012. The use of Partial Least Squares Structural Equation Modeling (PLS-SEM). Thousand Oaks: Sage.

Henseler, J., Ringle, C. \& Sarstedt, M. 2014. A new criterion for assessing discriminant validity in variance-based Structural Equation Modeling. Journal of the Academy of Marketing Science 43(1): 115-135.

Honig, B. 1998. What determines success? Examining the human, financial, and social capital of Jamaican microentrepreneur. Journal of Business Venturing 13(5): 371-394.

Honig, B. 2004. Entrepreneurship education: Toward a model of contingency-based business planning. Academy of Management Learning \& Education 3(3): 258-273.

Hsu, D.H. \& Ziedonic, R.H. 2013. Resources as dual sources of advantage: Implications forvaluing entrepreneurial-firm patents. Strategic Management Journal 34(7): 761-781.

Hult, G.T., Hurley, R.F. \& Knight, G.A. 2004. Innovativeness: Its antecedents and impact on business performance. Industrial Marketing Management 33(5): 429-438.

Indarti, N. \& Langenberg, M. 2004. Factors affecting business success among SMEs: empirical evidences from Indonesia. Paper presented at the Second Bi-Annual European Summer University, Encschode, Netherland.
Jack, S.L. 2010. Approaches to studying networks: Implications and outcomes. Journal of Business Venturing 25: 11201137.

Kara, O., Chu, H.M. \& Benzing, C. 2010. Determinants of entrepreneur's success: Evidence from Turkey. Journal of Business and Entrepreneurship 22(2): 1-15.

Keizer, J.A., Johannes, L.D. \& Halman, I.M. 2002. Explaining innovative efforts of SMEs: An exploratory survey among SMEs in the mechanical and electrical engineering sector in the Netherland. Technovation 22(1): 1-13.

Kim, P.A., Aldrich, H.E. \& Keister, L.A. 2006. The impact of financial, human, and cultural capital on entrepreneurial entry in the United States. Small Business Economics 27(1): 5-22.

Liao, D. \& Sohmen, P. 2001. The development of modern entrepreneurship in China. Stanford Journal of East Asian Affairs 1: 27-33.

López, S. 2005. Competitive advantage and strategy formulation: The key role of dynamiccapabilities. Management Decision 43(5/6): 661-669.

Lussier, R.N \& Shaike, M. 2014. A business success versus failure prediction model for small business in Israel. Business and Economic Research 4(2): 63-81.

Madrid-Guijarro, A., Garcia-Perez-de-Lema, D. \& Van Auken, H. 2013. An investigation of Spanish SME innovation during different economic conditions. Journal of Small Business Management 51(4): 578-601.

Manimala, M. 1992. Entrepreneurial heuristics: A comparison between high PI (Pioneering Innovative) and low PI ventures. Journal of Busines Venturing 7: 477-504.

Martínez-Román, J.A., Gamero, J. \& Tamayo, J.A. 2011. Analysis of innovation in SMEs using an innovative capability-based non-linear model: A study in the province of Seville (Spain). Technovation 31(9): 459-475.

Masurel, E. \& Smit, H. 2000. Planning behavior of small firms in central Vietnam. Journal of Small Business Management 38(2): 96-102.

Mazzarol, T., Reboud, S. \& Soutar, G.N. 2009. strategic planning in growth oriented small firms. International Journal of Entrepreneurial Behaviour \& Research 15(4): 320-345.

Meso, P. \& Smith, R. 2000. A resource-based view of organizational knowledge management systems. Journal ofKnowledge Management 4(3): 224-234

Ministry of Finance Malaysia. 2017. Economic Report 2017/2018. Putrajaya: Malaysia. Treasury Malaysia.

Mitchell, R., Busenitz, L., Lant, T., McDougall, P., Morse, E. \& Smith, J. 2002. Toward a theory of entrepreneurial cognition: Rethinking the people side of entrepreneurship research. Entrepreneurship Theory and Practice 27(2): 93-104.

Newbert, S.L. 2007. Empirical research on the resource-based view of the firm: An assessment and suggestions for future research. Strategic Management Journal 28(2): 121-146.

Nunally, J.C. \& Bernstein, I.H. 1994. Psychometric Theory. 3rd edition. New York: McGraw-Hill.

Olson, P.D., Zulker, V.S., Danes, S.M., Stafford, K., Heck, R.K.Z. \& Duncan, K.A. 2003. The impact of the family and business on family business sustainability. Journal of Business Venturing 18: 639-666.

Omri, A. \& Ayadi-Frikha, M. 2014. Constructing a mediational model of small business growth. International Entrepreneurship on Management Journal 10(2): 319342. 
Omri, A. \& Frikha, M. 2012. How entrepreneurs identify opportunities and access to external financing in Tunisian's micro-enterprises?. African Journal of Business Management 6(12): 4635-4647.

Orser, B.J., Hogarth-Scott, S. \& Riding, A. 2000. Performance, firm size and management problem solving. Journal of Small Business Management 38(4): 42-58.

Peteraf, M.A. 1993. The cornerstones of competitive advantage: A resource-based view. Strategic Management Journal 14(3): 179-191.

Pisturi, D., Welsch, H. \& Roberts, J. 1997. The re-emergence of family business in the transforming Soviet Bloc. Family Business Review 10(3): 221-37.

Powell, G.N. \& Eddleston, K.A. 2013. Linking family-tobusiness enrichment and support to entrepreneurial success: do female and male entrepreneurs experience different outcomes? Journal of Business Venturing 28(2): 261-280.

Risseeuw, P. \& Masurel, E. 1994. The role of planning in small firms: Empirical evidence from a service industry. Small Business Economics 6: 313-322.

Roberts, P.W. \& Amit, R. 2003. The dynamics of innovative activity and competitive advantage: The case of Australian retain banking, 1981 to 1995. Organisation Science 14(2): 107-122.

Robinson, R.B. \& Pearce, J.A. 1983. The impact of formalised strategic planning on financial performance in small organisations. Strategic Management Journal 4: 197207.

Rogers, M. 2004. Networks, firm size and innovation. Small Business Economics 22(2): 141-153.

Rogoff, E.G. \& Heck, R.K.Z. 2003. Evolving research in entrepreneurship and family business: recognizing family as the oxygen that feeds the fire of entrepreneurship. Journal of Business Venturing 18: 559-566.

Santarelli, E. \& Vivarelli, M. 2007. Entrepreneurship and the process of firms' entry, survival and growth. Industrial and Corporate Change, Industrial and Corporate Change 16(3): 455-488.

Shane, S. \& Delmar, F. 2004. Planning for the market: Business planning before marketing and the continuation of organizing efforts. Journal of Business Venturing 19: 767- 785 .

Shane, S. 2000. Prior knowledge and the discovery of entrepreneurial opportunities. Organisation Science 11(4): 448-469.

Shrader, C., Taylor, L. \& Dalton, D. 1984. Strategic planning and organizational performance: A critical appraisal. Journal of Management 10(2): 149-71.

Slater, S.F. 1997. Developing a customer Value-Based Theory of the firm. Journal of Academy of Marketing Science 25(2): 162-167.

Small Business Administration (SBA). 2014. Frequently asked questions about small business. Available at http:www.sba. gov/sites/default/files/FAQ_March_2014_0.pdf

Stam, W., Arzlanian, S. \& Elfring, T. 2014. Social capital of entrepreneurs and small firm performance: A meta-analysis of contextual and methodological moderators. Journal of Business Venturing 29(1): 152-173.

Tan, C.L., Goh, Y.N., Yeo, S.F., Ching, S.L. \& Chan, H.S 2017. An examination of the factors influencing the green initiative and competitiveness of private higher education institutions in Malaysia. Jurnal Pengurusan 57: 87-99.
Teece, D.J., Pisano, G. \& Shuen, A. 1997. Dynamic capabilities and strategic management. Strategic Management Journal 18(7): 509-533.

Teoh, W.M.Y. \& Chong, S.C. 2008. Improving women entrepreneurs in small and medium enterprises in Malaysia: Policy recommendations. Communications of the IBIMA 2008.

Thornhill, S. 2006. Knowledge innovation and firm performance in high- and low- technology regimes. Journal of Business Venturing 21(5): 687-703.

Tipu, S.A.A. \& Arain, F.M. 2011. Managing success factors in entrepreneurial ventures: A behavioral approach. International Journal of Entrepreneurial Behavior \& Research 17(5): 534-560.

USDA's Foreign Agricultural Service. 2018. Assessments of commodity and trade issues made by USDA staff and not necessarily statements of official U.S. government policy. Annual Report.

Wernerfelt, B. 1984. A resource-based view of the firm. Strategic Management Journal 5: 171-80

Yanadori, Y. \& Cui, V. 2013. Creating incentives for innovation? The relationship between pay dispersion in R\&D groups and firm innovation performance. Strategic Management Journal 34(12): 1502-1511.

Yueh, L. 2007. China's Entrepreneurs. Discussion Paper Series, Department of Economics, Pembroke College, Univeristy of Oxford, Oxford, March.

Zehir, C., Sahin, A., Kitapci, H. \& Ozsahin, M. 2011. The effects of brand communication and service quality in building brand loyalty through brand trust; The empirical research on global brands. Procedia Social \& Behavioral Sciences 24: $1218-1231$.

Zott, C. 2003. Dynamic capabilities and the emergence of intraindustry differential firm performance: Insights from a simulation study. Strategic Management Journal 24: 97-125.

Bee Leong Tan

Thompson Tan \& Associates

11, Persiaran Mahsuri 2/1

Sunway Tunas, Bayan Baru

11900 Bayan Lepas, Pulau Pinang, MALAYSIA.

E-Mail: thompbltan@yahoo.com

Cheng Ling Tan (corresponding author)

Graduate School of Business

Universiti Sains Malaysia

11800 USM Pulau Pinang, MALAYSIA.

E-Mail: tanchengling@usm.my

Sook Fern Yeo

Faculty of Business

Multimedia University

75450 Bukit Beruang, Melaka, MALAYSIA.

E-Mail: yeo.sook.fern@mmu.edu.my

Sock Lee Ching

Graduate School of Business

Universiti Sains Malaysia

11800 USM Pulau Pinang, MALAYSIA.

E-Mail: sllisa04@gmail.com 
APPENDIX A

QUESTIONNAIRE

Questionnaire Items

\begin{tabular}{|c|c|c|}
\hline Construct & Items & Item Description \\
\hline \multirow[t]{5}{*}{ Business Success } & BS1 & My restaurant business has increased. \\
\hline & BS2 & My business profit margin has increased \\
\hline & BS3 & My business is very successful \\
\hline & BS4 & I am very satisfied with my business success. \\
\hline & BS5 & My business success has met more than I expected \\
\hline \multirow[t]{7}{*}{ Innovation } & IN1 & My restaurant frequently tries out new ideas. \\
\hline & IN2 & My restaurant introduces number of new menu and services. \\
\hline & IN3 & My restaurant is first to market with new products or services. \\
\hline & IN4 & My restaurant is creative in its methods of operation. \\
\hline & IN5 & My restaurant develops new market segments. \\
\hline & IN6 & My restaurant uses new marketing methods. \\
\hline & IN7 & My restaurant develops new ways of establishing relationships with customers. \\
\hline \multirow[t]{3}{*}{ Start-up Planning } & SP1 & I carefully planned the capital requirement and timing of the launch of the venture. \\
\hline & SP2 & I carefully planned the technology used and source of funding. \\
\hline & SP3 & $\begin{array}{l}\text { Preparation of detailed business plan before starting marketing efforts has positive } \\
\text { impact on my business venture success. }\end{array}$ \\
\hline \multirow[t]{5}{*}{ Financial Support } & FS1 & Financial support is important to my involvement in developing self-enterprise. \\
\hline & FS2 & Start-up capital is important to my involvement in developing self-enterprise. \\
\hline & FS3 & $\begin{array}{l}\text { Access to credit from banks is important to my involvement in developing } \\
\text { self-enterprise. }\end{array}$ \\
\hline & FS4 & $\begin{array}{l}\text { Access to credit from non-governmental organisation is important to my involvement } \\
\text { in developing self-enterprise. }\end{array}$ \\
\hline & FS5 & $\begin{array}{l}\text { Access to credit from government is important to my involvement in developing } \\
\text { self-enterprise. }\end{array}$ \\
\hline \multirow[t]{4}{*}{ Networking } & NW1 & I spent time to establish and manage large networks. \\
\hline & NW2 & I cooperate with technology partners in business. \\
\hline & NW3 & I cooperate with marketing partners in business. \\
\hline & NW4 & I cooperate with financial partners in business. \\
\hline \multirow[t]{3}{*}{ Family Support } & FMS1 & $\begin{array}{l}\text { Family members often go above and beyond what is normally expected in order to } \\
\text { help my business succeed. }\end{array}$ \\
\hline & FMS2 & My family gives me useful feedback about my ideas concerning my business. \\
\hline & FMS3 & Family members often contribute to my business without expecting to be paid. \\
\hline \multirow[t]{6}{*}{ Government Support } & GS1 & $\begin{array}{l}\text { My business does not face problem in contacting the government during } \\
\text { business operation. }\end{array}$ \\
\hline & GS2 & Government provides adequate infrastructure to run my business. \\
\hline & GS3 & Government is helpful with my business license application and registration process. \\
\hline & GS4 & Government policy is favorable to run my business. \\
\hline & GS5 & Government helps to maintain law and order situation to my business. \\
\hline & GS6 & Overall, government support for my business is adequate. \\
\hline
\end{tabular}

